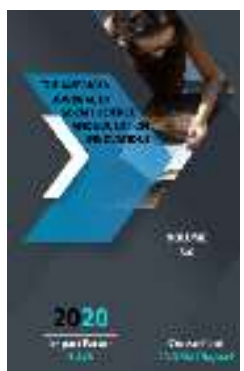

Journal

Website: http://usajournalshub.c om/index,php/tajssei

Copyright: Original content from this work may be used under the terms of the creative commons attributes 4.0 licence.

\section{Theoretical Provisions For The Development Of The Communicative Competence Of Students In A Foreign Language In Their Professional Domains Through Modular Training}

N.Kh. Khalmuradova

Phd, Samarkand State University, Samarkand, Uzbekistan

\title{
ABSTRACT
}

The types of competencies began to increase in the scientific literature with the development of the theory and practice of competence-based approach in higher education. The problem of the development of key competences has arisen which are applied universally in a variety of situations. Theoretical foundations of key competencies and their features in developing the communicative competence of students in a foreign language in their professional domains are analyzed in the article. The modern methodology of teaching a foreign language is based on the following principles of the competence-based approach to teaching oral speech which serve as the theoretical basis for the development of integrative modules for teaching a foreign language.

\section{KEYWORDS}

Foreign language communicative competence, modular training, integrative modules, competencebased approach, integrative approach, student-centered approach, pedagogical taxonomy, professional vocabulary.

\section{INTRODUCTION}

The types of competencies began to increase in the scientific literature with the development of the theory and practice of competence-based approach in higher education. In the light of the development of the practices in the competence-based approach in higher education, J. Raven (2001) presented a list of 37 competences within the framework of the European project for the implementation of the competence-based approach in higher vocational education. Here, 85 properties were identified, and a group of scientists from the German Institute for Research in Education found 654 properties in German literature titles. This vector of development could lead to the deprivation of 
the very idea of a competence-based approach.

The problem of the development of key competences has arisen, which are applied universally in a variety of situations: "Key professional competences are the ability of specialists to solve problems that arise in front of him/her in the process of a professional career and does not depend on the profession or specialty (invariant in relation to them). Every specialist should master it. They are versatile and applicable in a wide variety of situations". [Avliyakulov, N.H., Musaeva, N.N. (2014)] The meaning of the core competences is disclosed in the document "Key competences for Europe", which indicates that it includes the following [Troyanskaya, S.L. (2016)]:

- Learning Process - it implies that competence is the ability to transform knowledge into experience, and experience into activity, to generalize and systematize knowledge; organize his/her own educational process; be able to solve problems of various kinds, take responsibility for his/her own education;

- The Processes Of Research And Search implies that competence is the ability to work with various sources of information, with a book, knowledge of the basics of the scientific organization of labor, planning and implementation of research work;

- The Organization Of The Thought Process - refers to the ability to see the relationship between phenomena, to carry out the transfer of knowledge, to evaluating the phenomena of reality, and to be able to analyze, synthesize, compare, abstract, generalize, form judgments and inferences;

- Communication - refers to the presence of skills of speaking in an audience, i.e. the ability to listen and then to speak, and to be able to defend one's point of view, and also to be able to express one's thoughts orally and in writing. In the process of communication, the formation and development of the personality takes place, and this ensures one's entry into the society or in any sphere of life. [McClelland, D.C. (1971)] The main functions of communication are:

* information and communication (reception and transmission of information);

* regulatory and communicative (organization of interaction between people in their joint activities).

\section{METHODOLOGY AND METHODOLOGICAL FOUNDATIONS}

Theoretical foundations of key competencies and their features in developing the communicative competence of students in a foreign language in their professional domains. [Wiek, A., Withycombe, L., \& Redman, C. L. (2011)]

On this basis, the Council of Europe has identified five key competences:

*Political And Social Competences - i.e., to participate in the support and development of democratic institutions, to take responsibility, to resolve conflicts non-violently, to participate and accept group resolutions;

* Competences Related To Life In A Multicultural Society - i.e., the ability to live with people of a different culture, language, and religion;

* Competences Related To The Mastery Of Oral And Written Communication - i.e., the knowledge of more than one language is becoming increasingly important in the domains of professional activity and social life;

* The Ability To Learn Throughout Life - i.e., to build a foundation for lifelong learning in the 
contexts of personal, professional and social life.

The following six main key competencies have been distinguished in the Russian scientific and pedagogical literature [Troyanskaya, S.L. (2016)]:

- The ability for independent cognitive activity;

- The ability to independently solve problems in the field of social and labor activities, and in public, cultural, leisure, and household domains;

- Communication skills leading to intercultural understanding;

- Ability to project activities;

- The ability to create conditions that ensure safety and health;

- The ability to navigate in the world and to create one's own world as an environment for spiritual selfdevelopment, for the choice of spiritual values, and for the readiness for a profession.

The key competencies offered by Uzbek scientists can be distinguished [Avliyakulov, N.H., Musaeva, N.N. (2014)] as the following:

1. Information competence:- to interpret, systematize, critically evaluate, and analyze the information received from the perspective of the problems being solved;

2. Social and communicative competence:- to correlate his/her aspirations with the interests of other people and social groups;

- to represent and defend in a civilized manner one's own point of view in dialogue and public speaking on the basis of recognition of various positions and respectful attitude to the values (religious, ethical, professional, personal) of other people; [Holliday, A. (1994)]

3. Competence in problem solving:

- To identify and analyze problems;

- To transform problems and tasks;

- To set realistic and diagnostic goals;

- To plan and organize one's activities;
4. Ability to behave effectively in the labor market:

- Job searching skill;

- The ability to conclude a contract with employers;

- The ability to analyze the situation in the labor market;

5. Entrepreneurial competence:

- The ability for self-employment;

- An adequate assessment of one's entrepreneurial abilities and inclinations.

6. Ability for professional growth and continuous self-education:

- To identify problems in relation to one's knowledge and skills;

- To formulate educational and information requests competently;

- To assess the need for this or that information for one's activities;

The following provisions, formed in psychology [Seyitkhalilov, E.A. (2011)], have been adopted as a theoretical basis for identifying key competences:

- A person is a subject of communication, cognition, and labor [Brumfit C.J. (1984)];

- A person is manifested in the system of attitudes towards society, to other people, towards oneself, and towards work [Canale, M. (1983)];

- Human competence has a vector of acmeological development [Hutmacher, W. (1997)];

- Professionalism includes competence [Douglas, B.H. (2000)].

Graduates of a bachelor's degree of non-language higher educational institutions (faculties) must master the "B-2" level of the European International Standard for the Study of a Foreign Language in accordance with the State Standard for a Foreign Language. This level is characterized as the level of independent communication in a foreign language. 
The theoretical foundations of the methodology are based on a system of certain principles. Analysis of the content of these principles contributes to their effective use and development. The teaching methodology as a whole develops in accordance with the social order for education. The modern methodology of teaching a foreign language is based on the following principles of the competence-based approach to teaching oral speech [Finocchairo M., Brumfit C.J. (1983)]:

1. The principle of communicative orientation. This principle permeates all stages of organizing speech training. Any speech is subjective, and is creative linguistic activity of a person that reflects his/her cultural experience. It is variable and depends on the environment of communication. Oral speech represents communication using verbal means, perceived by hearing, and is associated with situational orientation and speech motivation. Speech performs various social functions such as: business, colloquial, formal, and informal. [Widdowson, H. G. (2001)] Before a person articulates a phrase, he/she has a motive for this action which the person then programs into an utterance by constructing it lexically and syntactically in a pragmatic context. The process of articulating a phrase can be seen in Fig. 2.1.

The speaker's speech is called expressive and the speech activity of the perceiver is called cognitive or directive speech. It is associated with analysis - the dismemberment of the perceived speech into its component parts whose elements are essential for the synthesis of the individual elements of speech and the notional (semantic) scheme (see Fig.2.2.).

2. The principle of the competence-based approach means the orientation of the process of teaching a foreign language to the acquired competences by the students that are necessary for their successful professional activity in the social, professional and scientific spheres. This principle requires teachers of a foreign language to not only teach grammar of a language but focus more on speech activity that results in communication. [Hymes, D.H. (1981)]

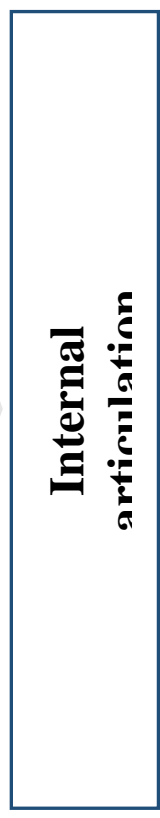

Verbalizatio n of internalized expressions 
Figure: 2.1. Diagram of the process of articulating a phrase (speech).

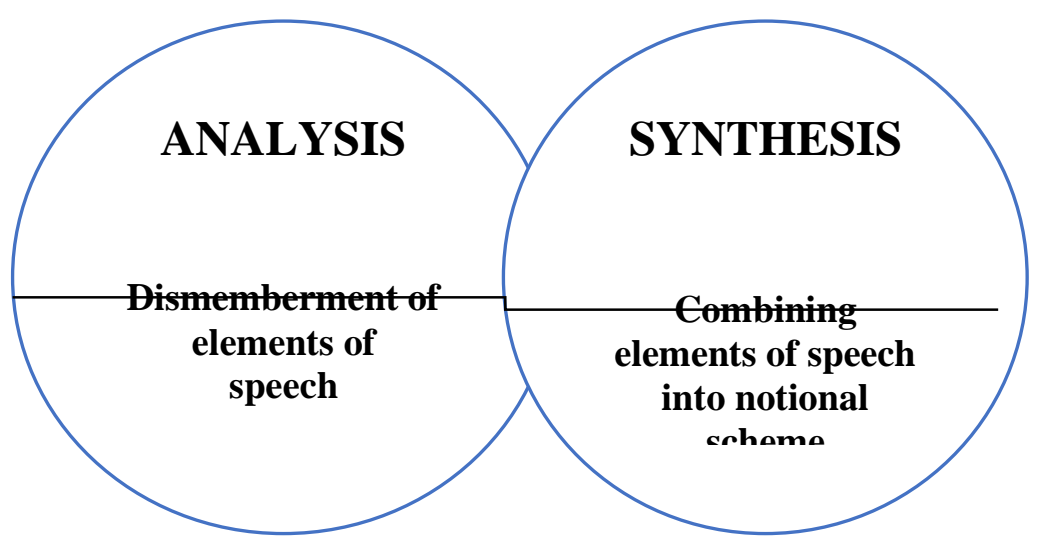

Figure: 2.2. Diagram of the process of speech perception.

\section{THE ANALYSIS AND INTERPRETATION OF RESULTS}

On the basis of the integration of the fundamental provisions of the competencebased approach, pedagogical technology and modular training, the methodology of teaching a foreign language, we have developed the principles for the development of communicative competence of students in a foreign language in their respective professional non-language domains of higher educational institutions, which serve as the theoretical basis for the development of integrative modules for teaching a foreign language. [Raven, J. (2001)] These include:

1. The principle of the competence-based approach - this refers to the development of students' abilities to independently solve problems in various fields and activities in the context of the modern globalized world. Educational materials, exercises mastered in foreign language classes in the higher education system, should be focused on the future activities of a specialist, including in the professional, scientific and social spheres. This principle requires the following:

(i) that the educational material on the discipline of 'Foreign language' reflects the current state of the accumulated experience of activities in the framework of a specific direction of education and its development prospects;

(ii) 'to teach to learn', i.e., to use a foreign language for continuous improvement of professional competence in the process of labor activity based on the use of foreign scientific and technical information, and communication in various forms with foreign specialists. 
2. The principle of an integrative approach means that teaching a foreign language should be carried out on the basis of knowledge, skills, and abilities acquired during the study of professional and other disciplines that contribute to the simultaneous development of professional communicative and social communicative competence.

This principle is most effectively implemented under the following conditions:

- Organization of research work, search work on the problems of professional activity in a foreign language within the context of the contextual approach;

- Organization of the process of teaching a foreign language, directed communication based on scientific literature, including foreign sources in a specific direction of education.

3. The principle of motivation - refers to the formation of value orientations towards learning a foreign language. The main value component is the formation of the student's desire to develop the professional competence of students through the achievement of knowledge of a foreign language. Possession of knowledge, skills, abilities to use the language are necessary for continuous improvement of professional competence on the basis of systematic acquaintance with modern foreign achievements in the field of professional activity from foreign scientific and technical information, materials and reports of international conferences, communication with foreign experts, and through the implementation of joint projects.

4. The principle of reliance on professional vocabulary refers to the development of communicative competence of students in a foreign language in their respective professional domains for the implementation of activities in the scientific and professional sphere on the basis of the selection, grouping and modular mastering of basic concepts of the direction of education.

7. Vocabulary is a linguistic category and represents the lexical sets of a language, a set of words of a particular language. It is the central part of the language that names and conveys knowledge about the various objects and phenomena. The vocabulary of each language consists of two large layers: commonly used words; and

(ii) special vocabulary (i.e., professional vocabulary or terms representing basic concepts inherent in a certain profession; jargon and special use of language forms etc.).

5. The scientific principle refers to fact that educational material for the study of a foreign language (module) must have scientific significance and must contribute to the development of the student's professional competence. This is in demand by the peculiarities of the development of the modern information society, functioning in the context of the globalization of the world economy. In these conditions, modern specialists constantly need to know a foreign language, for systematic familiarization with foreign scientific and technical information and advanced experience in the field of their professional activities. Only then he/she can be a successful specialist.

6. The principle of purposefulness refers to the establishment of a clear, unambiguously understood system of educational aims for an educational discipline with their classification into categories and sequential levels using pedagogical taxonomy. The aims of teaching must be measurable. Bloom's improved pedagogical taxonomy includes the following eight categories of learning goals: presentation, knowledge, understanding, application, analysis, synthesis, evaluation, and attitude. The use of pedagogical taxonomy is carried out with the help of verbs adequate to the categories of educational aims. That is, the educational aim should be described so that 
its achievement could be judged unambiguously.

7. The principle of the modular-linguistic approach refers to the development of integrative modules, in which each module is responsible for the mastering of certain linguistic competencies by students. An integrative module is a logically complete unit of educational material, covering a group of interrelated basic concepts of the direction of education on the relevant topic, aimed at mastering the prescribed number of linguistic competencies by students. Modularity, ensured by the gradual assimilation of educational material, when training goes from simple-to-complex for each module, manifests itself in the variability of the forms and methods of mastering each module.

8. The principle of the development of the student's personal qualities refers to the constant expansion of one's capabilities and the needs. For a person, not only his/her position is essential, but also the ability to realize his/her relationship. It depends on the level of development of a person's activity related capabilities and his/her abilities, knowledge, skills, emotionality, volition and intellectual qualities.

\section{DISCUSSION}

The activity of a person is characterized by the ability of a person to make a socially significant transformation of the material and spiritual environment on the basis of mastering the social and historical experience of mankind. It manifests itself in creative activity, and volitional aspects of communication. At the heart of the modern scientific, technical and social process lies precisely the activity of the individual, which makes specific requirements for training and education. Motivation plays a significant role in enhancing learning. The latter has different levels of activity: activity of production, activity of interpretation, and creative activity. Cognitive activity is stimulated by active teaching methods. The basis of active teaching methods is dialogue.

The teaching methods involve modeling the subject and social content of the student's future professional activity, which is already associated with the teacher's competence. Thus, this requires the inclusion of the student at the level of personal and social active, and this should be considered as the strategic direction of enhancing learning. Without a certain level of student activity, expressed at least in the elementary acts of attention, no learning can place.

\section{CONCLUSION}

1. Comparative analysis made it possible to substantiate the presence of signs of key competences in the category of communicative competence of students in a foreign language in their respective professional domains. The key competences are 'communication', 'cooperation', and 'adaptation' and 'foreign language acquisition'. It follows from this that every graduate of a higher educational institution, regardless of the direction of education, must acquire a communicative competence in a foreign language for their professional domains, which would be sufficient for the successful implementation of activities in the social, professional, scientific spheres of the multicultural world.

2. The principles and methodology of teaching a foreign language have been developed in accordance with the peculiarities of the social order of modern information for the training of specialists in higher education. The necessity of teaching a foreign language with the orientation of mastering the necessary competences in the corresponding direction of education is substantiated by the use of a competence-based approach. This gives relevance to the principle of developing students' creativity when teaching a foreign language. 
3. As a theoretical basis for the development of integrative modules for teaching a foreign language, on the basis of the integrative fundamental provisions of the competence-based approach, pedagogical technology, modular training and methodology of teaching a foreign language, the principles of development of communicative competence of students in a foreign language for the betterment of their professional non-language domains in higher educational institutions have been developed, which include: competencebased approach; the principle of an integrative approach; the principle of motivation; the principle of reliance on professional vocabulary; the principle of purposefulness; the principle of the modular-linguistic approach; and the principle related to the development of the student's personal qualities.

\section{REFERENCES}

1. Avliyakulov, N.H., Musaeva, N.N. (2014). The beginning of didactics. Tashkent. Science and Technology. p. 131

2. Bloom, B., Engelhart, M., Furst, E., Hill, W., \& Krathwohl, D. (Eds.) (1956). Taxonomy of Educational Objectives: The Classification of Educational Goals, Handbook I: Cognitive Domain. New York: David McKay

3. Bologna (1999) The European Higher Education Area. Joint Declaration of the European Ministers of Education. [online]. Available from: http://www.cepes.ro/ information_services/sources/on_line/ bologna.htm. Ac . Acessed $19 \mathrm{Apr}$ 2004.

4. Brumfit C.J. (1984). Communicative methodology in language teaching: the roles of, fluency and accuracy. Cambridge: Cambridge University Press.
5. Canale, M. (1983). From communicative competence to communicative language pedagogy [Text] / M. Canale // Language and Communication. - New-York, London: Longman. pp. 2-29.

6. David L. Chiesa, Ph.D. (Ed.), Ulugbek Azizov, Ph.D.,Svetlana Khan, Klara Nazmutdinova, Komila Tangirova, (1996). Reconceptualizng Language Teaching: an in-service teacher education course in Uzbekistan (MS), (the year is not given) Education: the hidden treasure (Learning: The Treasure Within) "The main provisions of the Report of the International Commission on Education for the XXI century", UNESCO Publishing House, $p$. 20-21

7. Delors J. (Eds). (1996). International Education Commission for the 4th century. Education is a hidden treasure. Paris: UNESCO. S. 1-102; See also: UNESCO Report: The Hidden Treasure // VVM. 1997. No. 9. S. 22-27.

8. Douglas, B.H. (2000). Communicative competence [Text] / B.H. Douglas. Cambridge: Cambridge University Press. p. 102

9. Finocchairo M., Brumfit C.J. (1983). The functional-notional approach: from theory to practice. New York: Oxford University Press.

10. Holliday, A. (1994). Appropriate methodology and social context. [Text] / A. Holliday. Cambridge: Cambridge University Press, - p. 248.

11. Hutmacher, W. (1997). Key competencies for Europe / W. Hutmacher: report of the Symposium Berne, Switzezland 27-30 March, 1996. Council for Cultural Cooperation (CDCC) // Secondary Education for Europe. - Strasburg, p. 247.

12. Hymes, D.H. (1981). On communicative competence [Text] / D.H. Hymes // The Communicative Approach to Language 
teaching. - Oxford: Oxford University

Press. pp. 5-27.

13. Johnson, D. (2001). Teaching methods: learning in collaboration / D. Johnson, R. Johnson, etc. SPb: School of Economics. p. 255.

14. Littlewood, W. (2005). Communicative Language Teaching. Language Teaching Library [Text] / W. Littlewood. - Cambridge University Press. p. 158

15. McClelland, D.C. (1971). Education for competence. In H. Heckhausen \&W. Edelstein (Eds.). Proceedings of the 1971 FOLEB Conference. Berlin, Germany: Institut fiir Bildungsforschung in der Max-PlanckGesellschaft, in press.

16. Musinov S., Kubaev S., Kholmurodova N. (2017). Preparation of teachers' competence for modular training at the university. Lap. Lambert Academic publishing RU.p. 135

17. Seyitkhalilov, E.A. Rakhimov B.Kh., Madzhidov I.Kh. (2011). Pedagogical dictionary reference book. T: Sogdiana. p. 700.

18. Troyanskaya, S.L. (2016). Basics of the competence-based approach in higher education. Izhevsk: "Publishing Center". Udmur University. p. 176

19. Van Ek, J.A. (1987). Objectives for foreign language learning [Text] / J.A. Van Ek. - Strasbourg: Council of Europe, Council for Cultural Cooperation.

20. Widdowson, H. G. (2001). Teaching Language as Communication. [Text] / H.G. Widdowson. Britain: Oxford University Press. 376 p.

21. Wiek, A., Withycombe, L., \& Redman, C. L. (2011). Key competencies in sustainability: A reference framework for academic program development. Sustainability Science, 6: pp. 203-218. 